\section{R. Venter}

Prof. Rian Venter, Dept Historical and Constructive Theology, University of the

Free State

E-mail: rventer@ufs. ac.za

ORCID: https://orcid. org/0000-0002-10544007

DOI: http://dx.doi. org/10.18820/23099089/ actat.v39i2.1

ISSN 1015-8758 (Print) ISSN 2309-9089 (Online)

Acta Theologica 2019 39(2):1-8

Date Published:

13 December 2019

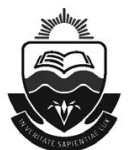

Published by the UFS http://journals.ufs.ac.za/index.php/at (C) Creative Commons With Attribution (CC-BY) ACCESS

\section{INTERVIEW - PROF. MARILYN NAIDOO}

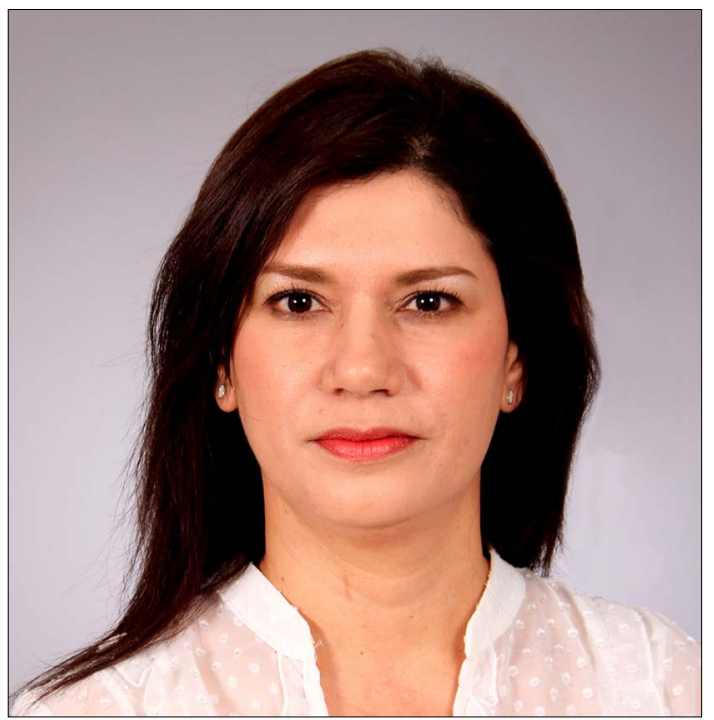

RV: Prof. Naidoo, you are a professor in Practical Theology in the School of Humanities at UNISA. You are an emerging scholar and researcher on theological education in South Africa. Thank you for giving Acta Theologica the opportunity to engage with you. Tell our readers something about your life and academic journey to UNISA.

MN: I felt a call to Christian work in 1989. My undergraduate theology training was an exhilarating time of learning at the Evangelical Bible Seminary of South Africa in the early 1990s, at the time of the political transition in South Africa. As we experienced the country's upheaval, this became the material we wrestled with in the theological classroom. As a multicultural student body, we were living together and experiencing each other for the very first time and considering what the new South Africa could look like. 
It was a time of finding our agency and identity as we studied and lived in community, all held together by formation - the motif being "God's shalom". This experience was life-changing and has provided me with a vision of what is possible in theological education, that we all can be humanly united under the Cross. We were involved in all kinds of social action, as part of our learning, with organisations such as Diakonia, Pietermaritzburg Agency for Christian Social Awareness and the Network of Independent Monitors. In addition, we studied ecumenically, were part of the Pietermaritzburg Cluster of Theological Institutions, and attended classes at partner institutions: St Joseph's Theological Institute; the Lutheran Theological Institute; the School of Theology of the then University of Natal, and even the Federal Theological Seminary of Southern Africa. This was an incredibly rich time of interaction and learning from other theological traditions, widening our horizons of the worldwide Church.

After my undergraduate studies, I worked in the local church ministry and overseas for a few years in community development on the border of India and Nepal, and in various theological training institutions in India. The Indian experience, on later reflection, had been about affirming my identity and Indian heritage which had been wounded by the apartheid system. I returned to South Africa to complete my postgraduate studies to continue teaching in India, and "fell into" academia when my supervisor Prof. Arthur Song offered me a research-assistant post at the University of Zululand. This developed into a permanent teaching post from 2001 to 2006 in the Department of Practical Theology and Religious Studies. I was also responsible for the new field of quality assurance and worked closely with eight theological colleges linked to the Faculty. However, in the restructuring process, this Faculty was closed. I was appointed as senior lecturer at UNISA in 2006 and was promoted to full professor in 2016. Over the years, I have taught Qualitative Research, Faith Development and Religious Education modules that have supported my postgraduate supervision and my overall research focus on theological education.

RV: Theological Education' is the central focus of your research work. What intrigues you about it? Is it still important at a public university?

MN: Yes, in the past fifteen years, my research has focused on surveying and documenting the state of the field of ministerial training within theological education in South Africa. Essentially, my research focus involves the professional development of religious leaders during theological education.

Since Christian leadership is a public role, theological students must be attuned to the issues of behaviour and accountability required of those who enjoy the community's trust. They would need some degree of psychological, 
anthropological and sociological understanding as well as a theological grasp of the human condition before God, and a multitude of personal qualities, which rest upon their self-knowledge and the character of their spiritual life. Theological institutions will have to take responsibility, in this regard, to help students develop this awareness and these personal qualities.

The Church assumes that theological institutions, including universities, ought to be shaping and forming church leaders who can serve the social needs of our country, be visionary with moral integrity, and be able to attend with competence to the many pastoral tasks at a local church level. But how does one achieve all these competencies within the future minister? It seems an impossible task! Yet we need to recognise that learning to be a minister encompasses the holistic development of individuals rather than being limited to acquiring knowledge about the faith or even knowing how to behave as a minister. It is about integrated human development. This is one of the main reasons why pedagogies of formation need to play a significant role in theological education. But this is easier said than done. We know that this integration of theory, practice and spirituality has been the enduring challenge within theological education, but if successfully integrated, it will definitely lead to a deeper sense of learning.

RV: "Formation" is a fundamental optic for you to approach theological education. What is at stake here? Is this possible at a public university?

MN: In the past few decades, there has been a growing emphasis on theological learning as ministerial formation, based on the assumption that the students' personal appropriation of theology is the most important aspect of theological education. It involves developing in students a complex of attributes involving critical thinking, the acquisition of knowledge, skills development, religious identity formation and the development of ministerial and spiritual maturity expected of church ministers. Formative education is based on didactic theories where the person is formed or moulded in terms of his/her total personality to become a mature and responsible person. Formative learning is focused on content and teaching methods, so that the person will take responsibility where the conscience is activated. For theology, students are apprenticed into a vocational identity, embodied in their very being. Graduates are thus supposed to know some important things about the tradition, to do those tasks required in the ministry of the church and to be persons of faith. Each of these three dimensions is informed by explicit or implicit theological understandings of the nature of human beings, of ministry, of leadership, and of context. Ministerial training involves more than just teaching students particular ways of thinking; it requires those ways of thinking to be linked constructively with ways of being and doing. I must add that, from my diversity study where I found 
racism embedded in institutional cultures, I realised that formative practices can serve as a resource. If done well, it has tremendous humanising potential to nurture in future leaders stable ministerial identities, by helping them reflect on how their social location and identity together with areas of psychological vulnerability shape the transition from seminary to ministry.

This formative education happens best in private denominational theological education as ministers are trained and formed within a particular ethos and tradition, led by faithful and exemplary teachers. This is because formative education involves the church as a major stakeholder, where faith, study and tradition inform one another. At the same time, many church traditions are also allowing students to study at universities, for reasons of access and affordability, and many choose to use distance education, however, this academic learning should be supplemented by a formational programme.

The landscape of theological education has changed in recent years by the restructuring of higher education, which has impacted on ministerial training. For private institutions, the introduction of accreditation, together with the high cost of residential education, brought on a radical review of ministerial formation programmes. For universities, the changes to a multi-faith stance has brought new debates on the role of Christian theology in the university, especially the place of confessional theology, and that dogmatics, practical theology and missiology are being taught in a confessional mode. Theology at universities should serve the public good; hence, the focus is on public theology and not on parochial church agendas. Ministerial formation in the public space is contested, as it raises issues as to whether it was possible to adequately pursue serious critical scholarship that may often come in conflict with the doctrinal position of the churches. If public funds are used, as with the use of the "kuratorium" in the previously Reformed universities, this could be viewed as discriminatory, as it positions a particular denomination.

University education supports the development of a critical perspective in students, committed to the need of interrogating all religious knowledge to avoid distortion. Students develop knowledge, understanding, vision and normative patterns that will guide them as church leaders. Because of the dissonance between educational philosophy and theological understanding of the person and of formation, doing formation at university would not be the ideal location. What would be appropriate within universities is to focus on values education, universal values embedded in courses such as ethical behaviour required of all professions. The challenge at universities is that there has been a great distance between the academy and the church, and that academic education is largely detached from concerns related to the faith commitment of the student. In addition, academic staff 
at universities are hired for their areas of specialisation and not trained to facilitate formation or are unwilling to do so. It would also be difficult to seek to instil a specific habitus among theology students in a university classroom where similar church backgrounds or at least shared vocational trajectories cannot be assumed. It is well known that many university graduates reach their ministerial posts with a great deal of intellectual knowledge, but with little practical understanding of how to lead and administer the church population. This lack of continuity between what theological students are learning in the classroom and what they need to know once they enter the ministerial context is a source of concern. To answer the question: Is formation possible in the university? Well, this church-related responsibility of theological education would be difficult to implement if the structural framework of the university does not allow emphasis on a ministerial formation.

RV: You have written extensively about related themes, for example, globalisation, distance education, Africanisation, and diversity. What are the current challenges facing theology at public universities in South Africa?

$\mathrm{MN}$ : There are various challenges facing theology: its place in the university, the transformation imperative in its various configurations, access to theological education, market-driven forces, issues of relevance and contextuality, world views, ideologies, and agendas for the future. Significant for theological education is the tension between the goals of higher education and those of theological education, because it shapes what is possible in terms of goals and visions of theological education. The university develops individuals within a market context of competition, while the Church seeks to form individuals to inhabit theological understandings, involving an understanding of personhood in community. This has all kinds of implications. For example, a recurring theme in theological education is the need for curricular and methodology changes within the curriculum. University faculties have become so diversified that theological disciplines are no longer able to converse meaningfully with one another. Each discipline has its own methodology and, hence, its own language. Because of this, it loses its capacity to reflect on a common goal and concern. On the other hand, students experience fragmentation and wrestle with combining the academic and vocational perspectives. Moreover, the openness of the curriculum itself aids the consumer mentality of our culture, thus reinforcing the character and values of students. In our corporatised structures of the university, where education and knowledge are commodified, we are left pandering to students as consumers whom we have to please. The issue of accreditation remains. While the goals of quality are appreciated, they are not contextualised 
to ministry profiles and do not develop the required characteristics and competencies in theological students. How to create humane teachinglearning communities and at the same time attend to many dimensions of structural change that still needs to take place, and so on.

RV: Much is being written about "decolonisation" for universities. What does this imply for theology and theological education? Are you positive about the changes (transformation!) taking place at theological institutions, are they adequate enough?

MN: We have to reckon with colonialism, as it has organised people into hierarchical relationships of dominance and oppression, has shaped mindsets, and continues to impact on progress. Racism has embedded itself in theological institutions, while cultures of whiteness and power discourses of resistance actively continue. In this liminal space, we have seen dramas playing themselves out with student protests and a demand for belonging and inclusion. We hear calls for curriculum transformation, indigenous knowledge advancement, and the Africanisation of the curriculum. This is aggravated by feelings of helplessness and a lack of trust among staff, students and mangement. We remain in an uncomfortable transitional space.

Decoloniality as a perspective shows that the violence caused by colonialism still exists. We need to retrieve identity wherever possible. To do this will involve greater competition within the discursive field. Asserting other knowledges creates the possibility that people can break free from the way in which a discourse defines them, and opens up for contingency and choice. The calls to decolonise and Africanise the western curriculum also mean more than just the inclusion of Black and African sources in curricula. It is concerned with the often unreflected cultural, epistemological and denominational presuppositions and attitudes that are sustained. The implications of a changed view of truth, power, culture, God and gods and all other issues need to be reckoned with. There should be greater epistemological inclusion and a call for White scholars to more actively join Black scholars in working against the processes that produce racism. In theological education, the social context should be a major element to be examined. Theological educators themselves must be uncomfortable while teaching in a context of unjust environments, as this holds direct consequences for students, identity and transformation.

Transformation of theological institutions and universities have a long way to go, as our society is anything but "normal". Within private institutions, there is very little awareness and incentive with a lack of gender and racial diversity. At universities, there is much resistance. To embrace the 
challenge could be a moment of revitalisation for theology, because it prompts theology to consider afresh its very nature, task and responsibility.

RV: You have undertaken several major research projects over the years. Tell the readers about your present project. Are you excited about possible outcomes?

MN: Because African scholarship should seek to find unique local ways of responding to the training of ministers, I am leading a research project funded by the African Theological Advance Grant, a grant developed by the Nagel Foundation in the US.

It is a collaborative and developmental research with the goal of understanding "Integrative theological education" within Protestant theological institutions in Africa (the sample involves the Baptist Theological College, Randburg, South Africa, Justo Mwale University, Lusaka, Zambia and Pentecostal Theological Seminary in Accra, Ghana). Integration here is defined as bring together the cognitive, affective and behavioural components of the practice of ministry so as not to perpetuate the theory-practice dichotomy. This project is enabling institutions to reflect on its curriculum design and to look for a renewed model for ministerial training that is holistic and embedded in African values.

Thus far we have made some interesting findings at each research; some include that a very academic and Western curriculum is in place in all locations. Academic staff appreciate the focus of holistic learning but evidence a lack of capacity in educational methods or formational education. Pedagogically, the shift from teaching to student-centred learning has not been made and there is not necessarily a correlation between theory and practice. Gender marginalisation was very much evident and the hidden curriculum and its formative potential needs to be prioritised. As part of its action research methodology, each site will work towards interventions that bring about holistic education which may involve for example, introducing vertical or horizontal integration into the curriculum, including an integrative capstone module, community formation practices or more robust partnerships with local churches for pastoral skills development.

RV: Our society is in the grip of radical changes and challenges. What does the future hold? What do you anticipate would happen to theology and theological education at the public university?

MN: There are two visions of theological education: one that merely reproduces the existing reality and one that challenges the status quo to create the possibility for a more just world. My overall vision is one that is engaging, critical, liberating and humanising. But to do that, one 
would have to fundamentally re-imagine theological discourse, curriculum, pedagogy, and institutional systems from a perspective of creating a "new humanism" that restores values and human relationships as central to the educational process.

We must make a more concerted effort to educate future leaders who will make a difference, as sometimes theological education can only be about credentialing for ministry jobs. It will involve examining not only the model of theological education, but also the product of theological education. Theology at the university will need to move away from sectional interests and play a greater role in influencing behaviour in society, such as, for example, focusing on values and moral development of society in terms of the family, gender relations or in the work of reconciliation. In developing relevance, there must be a dialogue with other disciplines and faculties. Pedagogically, this involves engaged, inductive pedagogies, fostering individual agency, promoting value-laden course content, and developing awareness of personal and social contextual influences.

For sustainable theological education, some reflection will have to be made on the effective use of information technologies for theological teaching, engaging diversity in theological education, the need for dialogue with indigenous theology, and the lack of interreligious dialogue and praxis. On the latter point, many churches have retreated and are barely open to ecumenical dialogue, not to speak of interfaith encounters. Students should be helped to reflect on their religious contexts and develop theologies that promote religious coexistence and respect for diversity. 